\title{
Cancer and palliative care: an issue of right human
}

\author{
Keywords: palliative care, chronicity, medicalization, biomedical
}

\section{Opinion}

Palliative care, as an approach to modern medicine, has a broad scientific support and intended to accompany and soften the struggle carried out by patients diagnosed with cancer. So, they must live up to the concern of attending these patients and their families about the mitigation of suffering. Despite of the available therapy, so often the chronicity of the disease irretrievably progresses. However, palliative care is distinguished from the current biomedical model, which categorically invests in the medicalization of death (therapeutic obstinacy), a process in which the maintenance of life without quality, meaning and sense is obstinate. They are also distinguished from the biomedical current directioned towards euthanasia, whose argument is morally justified by the prevention of suffering from that inherents to the chronic and longstanding incurable diseases. ${ }^{1}$

This current of the biomedical model invoque intense worldwide discussions concerning the possibilities of medicine in arbitrating about maintaining the life of someone with a burden of degrading and unnecessary suffering. The symbolic representation of severe illness and a negative perspective of near death atribute to the cancer, in the developed world, the great problem to be overcome and solved, among the great challenges of the health-disease complex. In most cancer deaths, patients are aware until the final moments of their existence. This fact direct the care for the own individuals of the attention. The ability to think the issue, in this way, implies in developing multidisciplinary approaches and interdisciplinary actions in the management of the care of people in peculiar and particular conditions.

The World Health Organization has adopted an expanded concept of Palliative Care, widely used in national literature and official documentation "that improves the quality of life... and impeccable assessment and treatment of pain and other problems, physical, psychosocial and spiritual". ${ }^{2}$ Human rights have been consolidated and defended in several international declarations and conventions. But in practice, what we see is a precariousness of life and a wide delegitimation of rights. Increasing numbers of non-citizens in peripheral countries are growing, forming civil societies but not civilians, societies of individuals without rights, without dignity, without citizenship, in a social production of absences or social forms of non-existence.

In countries where there is a perverse distribution of income, poor living and working conditions, and growing differences in social stratification, social inequities appear. ${ }^{4}$ These, submit individuals and communities to all kinds of risk and diseases, where access to cancer treatment and palliative care is inserted. There is no known culture that consider death without care, death with exacerbated suffering. When medical technology, even with the best intention, perpetuates the life of someone suffering from an incurable disease, what is exercised is the positive law of science and not the human right. The therapeutic obstinacy of modern medicine is more a 'culture' linked to the economic order, than a cultural manifestation, between generations, of the people in the management of inevitable death. Equalizing
Volume 2 Issue I - 2018

\section{Maria Cecília de Souza Minayo,' Ernani Costa Mendes, ${ }^{2}$ Luiz Carlos Fadel de Vasconcellos ${ }^{2}$}

'Fundação Oswaldo Cruz, Escola Nacional de Saúde Pública Sergio Arouca, Brazil

${ }^{2}$ Departamento de Direitos Humanos, Fundação Oswaldo Cruz, Brazil

Correspondence: Ernani Costa Mendes, Fundação Oswaldo Cruz, Escola Nacional de Saúde Pública Sergio Arouca, Departamento de Direitos Humanos, Saúde e Diversidade Cultural, Rio de Janeiro, Brazil, Email ernanicmendes@gmail.com

Received: November 22, 2017| Published: January 22, 2018

discrepancies in cancer care is a matter of justice. The recourse to equity is a suavization of the positive law, making it possible to see human things beyond the concrete things.

The rights of incurable and terminal patients for some time are treated as inalienable human rights. In Europe, Recommendation No. 1,418 on "Protection of Human Rights and Dignity of the Rights of Incurable and Terminally Ill Patients" has been set out in the Declaration of the Parliamentary Assembly of the European Council in 1999. In order to guarantee this fundamental human right, the international community ${ }^{1}$ has been publishing a set of important documents, such as The Cape Town Declaration (WHO, 2002), Korea Declaration (WPCA, 2005), Budapest Commitments, (EAPC, IAHPC, WPCA, 2007 ), Joint Declaration (IAHPC, WPCA, 2009), Morphine Manifesto (PALLIUM INDIA, 2010), Resolution -Access to Adequate Pain Treatment (WMA, 2011) and Prague Charter (EAPC; IAHPC; WPCA, 2012). ${ }^{6,7}$

These documents conclude that access to appropriate palliative care must guarantee the rights to the: life, health, information, nondiscrimination, autonomy, self-determination, consent or not to any treatment, privacy, not be subjected to inhuman and cruel treatment, to opt for the most favorable treatment; and to be free from torture and cruel, inhuman or degrading treatment. ${ }^{8}$ In 2017, the Report of the 67th WHO Assembly reinforces the need for development and implementation of palliative care policies at all levels of health care, equity of access, availability of drugs and also inclusion of palliative care training in the various levels of education to professionals of health system. ${ }^{9}$

Concern about the implementation and quality of palliative care is worldwide. Quantifying their structural, procedural and results aspects become guidelines for the proper functioning of the services that provide these care. In this context, the permanent need to monitor the quality of palliative care available to the population is accompanied by important groups in the world. An example is the Working Group

${ }^{1}$ International Palliative Care Communities as defenders Human Rights. World Health Organization (WHO), Worldwide Palliative Care Alliance (WPCA), European Association for Palliative Care (EAPC), International Association Hospice \& Palliative Care (IAHPC), Pallium India (ONG), World Medical Association (WMA). 
of the European Palliative Care Association, which monitors the development of palliative care in Europe as a model for the world, as well as the International Association of Hospitals and Palliative Care, whose vision is to provide access to palliative care integrating it at all levels of health systems.

\section{Acknowledgements}

None.

\section{Conflict of interest}

The author declares no conflict of interest.

\section{References}

1. Floriani CA, Schramm FR. Cuidados paliativos: interfaces, conflitos e necessidades. Ciênc saúde coletiva. 2008;13(supl 2):2123-2132.

2. WHO. National cancer control programmes: policies and managerial guidelines. 2nd ed. World health organization, OMS, Generva, Switzerland: Springer; 2002. p. 1-203.
3. Santos BS. Para uma sociologia das ausências e uma sociologia das emergências. Revista Crítica das Ciências Sociais. 2002;63:237-280.

4. Buss PM, Pellegrini Filho A. A saúde e seus determinantes sociais. Physis. 2007;17(1):77-93.

5. Bittar ECB. Curso de filosofia aristotélica- leitura e interpretação do pensamento aristotélico. Manole, São Paulo, Brazil: Springer; 2003.

6. Capelas MLV, Coelho SPF. Pensar a organização de serviços de cuidados paliativos. Revista de Cuidados Paliativos-Associação Portuguesa de Cuidados Paliativos. 2014;1(1):17-26.

7. Lima L. The right to palliative care as a human right. World congress ESPC, Prague: Springer; 2013.

8. Tristán LQ. Derechos Humanos y Cuidados Paliativos. Rev Med Hondur. 2008;76:39-43.

9. WHO. Cancer prevention and control in the context of an integrated approach. Seventieth world health assembly. World health organization, Switzerland: Springer; 2017. 